\title{
Redberry juniper canopy cover dynamics on western Texas rangelands
}

\author{
DARRELl N. UECKERT, ROBERT A. PHILlips, JOSEPH L. PETERSEN, X. BEN WU, AND DANIEL F. \\ WALDRON
}

Authors are professor, former graduate research assistant, and senior research associate, Texas Agricultural Experiment Station, 7887 U.S. Hwy. 87 North, San Angelo, Tex. 76901-9714, assistant professor, Rangeland Ecology \& Management Department, Texas A\&M University, College Station, Tex. 77843-2126, and associate professor, Texas Agricultural Experiment Station, San Angelo, Tex. 76901-9714.

\begin{abstract}
Knowledge of the rate woody plant canopy cover increases is essential for understanding the ecology of rangeland plant communities, determining the economic feasibility of brush management practices, and for scheduling initial and maintenance control practices. We determined rates of change in redberry juniper (Juniperus pinchotii Sudw.) canopy cover from the mid 1950s through the late 1990s at 5 locations in western Texas on rangeland that had been chained or grubbed for juniper control and on adjacent untreated areas. Juniper cover was estimated from aerial photographs by the line intercept method using a 10$\mathrm{X}$ monocular lens with a vernier. Juniper cover increased at 0.35 \pm 0.06 percentage units year $^{-1}$ on untreated sites and at $1.01 \pm$ 0.07 percentage units year $^{-1}$ following chaining or grubbing. Juniper cover returned to pre-treatment levels in an average of 20 years (range 11 to 25 ) following chaining or grubbing. Herbage production on untreated rangeland was predicted to decline slowly $\left(2.4\right.$ to $5.0 \mathrm{~kg} \mathrm{ha}^{-1}$ year $\left.^{-1}\right)$ as juniper cover increased from 6 to $14 \%$ and rapidly $\left(>8 \mathrm{~kg} \mathrm{ha}^{-1}\right.$ year $\left.^{-1}\right)$ as juniper cover increased from 30 to $38 \%$. Herbage production was predicted to decline at a constantly increasing rate following mechanical control of juniper, from $<2 \mathrm{~kg} \mathrm{ha}^{-1} \mathrm{year}^{-1}$ in year 1 to $23 \mathrm{~kg} \mathrm{ha}^{-1}$ year $^{-1}$ in year 29. Potential additional livestock carrying capacity due to juniper control would be under estimated by more than $40 \%$, assuming forage production without treatment remained constant during the entire planning horizon of an economic analysis. To avoid significant reductions in livestock carrying capacity, redberry juniper control should be implemented before its canopy cover exceeds about $20 \%$.
\end{abstract}

Key Words: Juniperus pinchotii, mechanical brush control, aerial photography, line transects, juniper management, herbage production

Redberry juniper (Juniperus pinchotii Sudw.) is a basal-sprouting conifer that usually has several stems arising from the base. It is believed to be a stabilized hybrid of alligator juniper ( $\mathrm{J}$. deppeana Steud.) and one-seed juniper [J. monosperma (Engelm.) Sarg.] that developed during the Pleistocene era (Hall and Carr 1968). Redberry juniper occurs in southwestern Oklahoma, western Texas, southeastern New Mexico, southern Arizona, and northeastern Mexico (Correll and Johnston 1970). Prior to devel-

Manuscript accepted 4 Nov. 00.

\section{Resumen}

Conocer la tasa de incremento de la cobertura de copa de las plantas leñosas es esencial para entender la ecología de las comunidades vegetales de pastizal, determinar la factibilidad económica de las prácticas de manejo de arbustos y para programar las prácticas de control inicial y de mantenimiento. En 5 localidades del oeste de Texas determinamos las tasas de cambio de la cobertura de copa del "Redberry juniper" (Juniperus pinchotii Sudw.) ocurridas de mediados de la década de los 50 's a finales de la década de los 90's. Las determinaciones se llevaron a cabo en un pastizal en el que el "Juniper" se controlo con cadeneo y extracción y en áreas adyacentes sin control de "Juniper". La cobertura de "Juniper se estimó de fotografías aéreas con el método de línea de intercepción utilizando un lente monocular de $10 \mathrm{X}$ con un vernier. En los sitios no tratados la cobertura de "Juniper" aumentó en $0.35 \pm 0.06$ porcentaje unidades año- ${ }^{-1}$ y en $1.01 \pm$ 0.07 porcentaje unidades año ${ }^{-1}$ después del cadeneo o extracción. La cobertura de "Juniper regresó a los niveles de pre-tratamiento en un promedio de 20 años (rango de 11 a 25 ) después del cadeneo o extracción. En los pastizales si tratamiento se predijo un disminución lenta de la producción de forraje $\left(2.4\right.$ a $5.0 \mathrm{~kg} \mathrm{ha}^{-1}$ año $^{-1}$ ) conforme la cobertura de "Juniper" aumentó de 6 a $14 \%$ y una disminución rápida (>8 $\mathrm{kg} \mathrm{ha}^{-1}$ año $\left.^{-1}\right)$ conforme la cobertura de "Juniper" aumentó de 30 to $38 \%$. Se predijo que la producción de forraje disminuira a una tasa constantemente mayor después del control mecánico del "Juniper", de $<2 \mathrm{~kg}$ año ${ }^{-1}$ en el año 1 a 23 $\mathrm{kg}$ año ${ }^{-1}$ en el año 29. La capacidad de carga animal potencial adicional debida al control de "Juniper"sería subestimada por mas de $40 \%$, asumiendo que la producción de forraje sin control permaneció constante durante el horizonte de planeación completo de un análisis económico. Para evitar reducciones significativas en al capacidad de carga animal el control de "Redberry juniper"debe ser implementado antes de que su cobertura de copa exceda el $20 \%$.

opment of the rangeland livestock industry, redberry juniper was primarily restricted to rocky outcrops and rocky, north-facing slopes where it was protected from intense grass fires (Ellis and Schuster 1968). Since the late 1800s, redberry juniper woodlands have rapidly spread and thickened on adjacent slopes and grasslands. A 1982 survey indicated that this species occurred on about 4.7 million ha of rangeland in Texas (Soil Conservation Service 1985). Redberry juniper infestations increased by about $60 \%$ (1.5 million ha) during the period 1948 to 1982 in a 65county region in northwestern Texas (Ansley et al. 1995). 
Excessive cover of redberry juniper is detrimental to rangeland livestock production, wildlife habitat quality, and rangeland watersheds. Herbaceous production declines as juniper canopy cover increases and as the plants mature (McPherson and Wright 1990a, Dye et al. 1995, Johnson et al. 1999). Only about $34 \%$ of annual rainfall reaches mineral soil beneath redberry junipers in western Texas because of interception by the canopy and litter layers (Thurow and Hester 1997).

Knowledge of the rate redberry juniper canopy cover increases is critical to better understanding its ecology, scheduling initial and maintenance control practices, and for assessing the economic feasibility of alternative control practices. Two relationships between woody plant canopy cover and time are important in economic analysis. First, the rate woody plant cover increases subsequent to a control practice determines the effective treatment life, which is defined as the length of time (years) for forage production to return to pretreatment levels (Conner 1985). Second, knowledge of the rate woody plant cover increases without treatment and subsequent to treatment is necessary to estimate additional herbage production due to treatment (Johnson et al. 1999). Two-way chaining followed by periodic prescribed burning was recently shown to be economically feasible for redberry juniper control (Johnson et al. 1999), but field data were not available on the rate of increase in juniper cover. Objective 1 of this study was to determine the rates of increase in redberry juniper canopy cover on untreated and mechanically treated rangeland in western Texas. Our hypothesis was that juniper cover increased faster following mechanical control than on untreated rangeland. This hypothesis was based on personal observations by the senior author of dozens of sites in the Edwards Plateau region of Texas where redberry juniper had been mechanically controlled. Objective 2 was to apply the knowledge gained in objective 1 to estimate the temporal effects of changes in redberry juniper cover on herbage production and livestock carrying capacity during the conversion of grasslands or juniper savannas to juniper woodlands.

\section{Materials and Methods}

\section{Study Sites}

Redberry juniper woodlands were studied at 5 locations across the northern and western Edwards Plateau region of Texas

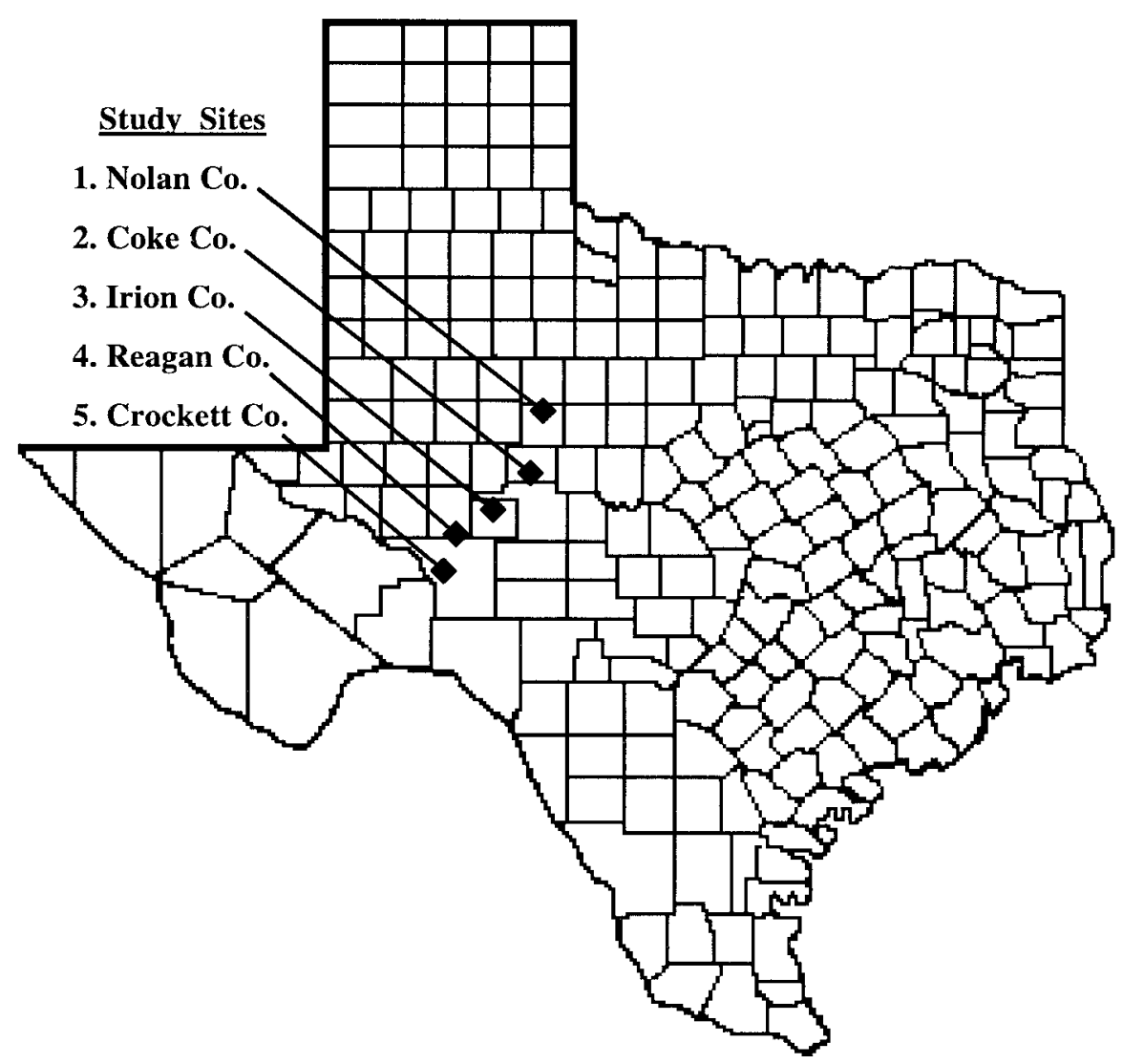

Fig. 1. Locations of redberry juniper study sites in the Edwards Plateau, Tex.

(Fig. 1) along an average annual rainfall gradient from 46 to $62 \mathrm{~cm}$. Two, 16.2-ha sites were selected at each location, 1 with and 1 without a history of mechanical control. The 2 sites were in close proximity, on similar soils, and were situated where man-made or topographical features facilitated locating the sites on large-scale aerial photographs. The study sites were selected where: (1) redberry juniper was the dominant overstory species and juniper cover was heavy; (2) no other large, evergreen woody species were present that could be mistaken for junipers on aerial photographs taken during winter; (3) maintenance juniper control treatments had not been applied subsequent to the initial mechanical control treatments; and (4) past grazing management was typical for the region.

Positive transparencies of all available aerial photographs (nominal scale 1:7,900) of each site were purchased from the USDA Farm Services Agency Aerial Photography Field Office in Salt Lake City, Utah. All photographs were taken during winter and redberry juniper plants or clusters were evident as dark patches within the grey matrix of dormant grasses and bare ground. Aerial photographs were taken in 1957, 1964, 1973, 1985, and 1996 for Coke County; 1963, 1985, and 1996 for Crockett County; 1955, 1964, 1977, 1985, and 1996 for Irion County; 1957, 1964, 1976, 1985, and 1996 for Nolan County; and 1961, 1985, and 1996 for Reagan County. Photographs for Coke County, undisturbed-1985; Irion County, mechanically controlled-1985; and Nolan County, undisturbed-1976 and mechanically controlled-1985 were not used because juniper canopies could not be readily distinguished.

Descriptions of the study sites and juniper control treatments are given in Table 1 . The soils at all sites were shallow with rapid surface runoff and low to very low water-holding capacity. Information about the soils was obtained from Barnhill (1974), Lowther (1981), Wiedenfeld (1986), C.C. Wiedenfeld (unpublished), and R. Dowell (unpublished).

\section{Estimating Redberry Juniper Canopy Cover}

Large-scale aerial photography has been effectively used for quantifying changes in woody plant canopy cover (Archer et al. 1988, Knapp et al. 1990, Soulé and Knapp 
Table 1. Study locations where redberry juniper canopy cover was estimated from aerial photographs.

\begin{tabular}{|c|c|c|c|c|c|c|}
\hline County & $\begin{array}{c}\text { Avg. } \\
\text { Rainfall }^{1}\end{array}$ & Treatment & N Lat & W Long & $\begin{array}{l}\text { Range } \\
\text { Site }\end{array}$ & Soil \\
\hline Coke & $\begin{array}{l}\left(\mathrm{cm} \mathrm{yr}^{-1}\right) \\
58.7\end{array}$ & $\begin{array}{l}\text { None and chained } \\
2 \text { ways in } 1970\end{array}$ & $31^{\circ} 43^{\prime}$ & $100^{\circ} 32^{\prime}$ & Low stony hill & $\begin{array}{l}\text { Tarrant association }{ }^{2} \\
\text { (shallow clays mixed } \\
\text { with stones) }\end{array}$ \\
\hline Crockett & 46.0 & $\begin{array}{l}\text { None and chained } \\
1 \text { way in } 1971\end{array}$ & $30^{\circ} 40^{\prime}$ & $101^{\circ} 33^{\prime}$ & Limestone hill & $\begin{array}{l}\text { Noelke-Ozona-Crocko } \\
\text { complex }{ }^{3} \text { (shallow silty } \\
\text { clay loams containing } \\
\text { many limestone } \\
\text { fragments) }\end{array}$ \\
\hline Irion & 49.2 & $\begin{array}{l}\text { None and chained } 2 \\
\text { ways in } 1972\end{array}$ & $31^{\circ} 23^{\prime}$ & $100^{\circ} 48^{\prime}$ & Limestone hill & $\begin{array}{l}\text { Ector series }{ }^{4} \text { (shallow, } \\
\text { loamy, very gravelly, } \\
\text { very stoney) }\end{array}$ \\
\hline Nolan & 62.2 & None and grubbed in 1976 & $\begin{array}{l}32^{\circ} 24^{\prime} \\
32^{\circ} 24^{\prime}\end{array}$ & $\begin{array}{l}100^{\circ} 20^{\prime} \\
100^{\circ} 17^{\prime}\end{array}$ & Loamy prairie & $\begin{array}{l}\text { Quinlan loams } \\
\text { (shallow, loamy soils on } \\
\text { uplands) }\end{array}$ \\
\hline Reagan & 46.8 & $\begin{array}{l}\text { None and chained } \\
2 \text { ways in } 1978\end{array}$ & $31^{\circ} 05^{\prime}$ & $101^{\circ} 28^{\prime}$ & Limestone hill & $\begin{array}{l}\text { Noelke series }{ }^{6} \text { (shallow, } \\
\text { very cobbly, silty clay } \\
\text { loams) }\end{array}$ \\
\hline
\end{tabular}

${ }_{2}$ Average annual rainfall for the period covered by aerial photographs for the respective sites.

${ }_{3}^{2}$ Tarrant soils are clayey-skeletal, montmorillonitic, thermic, Lithic Haplustolls.

${ }^{3}$ Noelke-Ozona soils are loamy-skeletal, mixed superactive, thermic Lithic Petrocalcic Calciustolls: Crocko soils are fine, smectitic, thermic Vertic Calciustolls.

${ }_{5}^{4}$ Ector soils are loamy-skeletal, carbonatic, thermic Lithic Calciustolls.

${ }^{5}$ Quinlan loams are loamy, mixed, thermic, shallow Typic Ustochrepts.

${ }^{6}$ Noelke soils are loamy-skeletal, mixed, thermic, shallow Petrocalcic Calciustolls.

1999, Wu et al. 2000, Ansley et al. 2001). In this study, a $10-\mathrm{X}$ hand lens with a vernier was used to estimate juniper cover by the line intercept method (Bonham 1989) on each 16.2-ha plot on the aerial photographs. Aerial photographs were placed on a light table during sampling. The center one hundred, $0.1-\mathrm{mm}$ increments of the vernier were used for line transects. The ground scale of a transect was $79 \mathrm{~m}$ with observations at a scale of $0.79 \mathrm{~m}$ on the earth's surface. Forty-five line transects were sampled per plot for each date. The mean canopy cover was calculated for each plot for each date.

\section{Data Analysis}

The rate of change in redberry juniper canopy cover (percentage units year ${ }^{-1}$ ) for each plot was calculated by dividing the percentage point change in cover from photograph A to photograph B (e.g., from 1957 to 1964) by the number of years that had lapsed between the 2 photographs. Live juniper cover remaining subsequent to application of mechanical control practices was assumed to be about $1 \%$ based on our observations of commercial chaining and grubbing operations in western Texas.

An aerial photograph within a year prior to application of the mechanical control treatment was available for only 1 of the treated sites. Juniper canopy cover prior to treatment for the other 4 treated sites was estimated using earlier pre-treatment canopy cover estimates and the pre-treatment rate of change for the plot. If too few pre-treatment photographs were available for determining pre-treatment rate of cover change, then the rate of cover change for the pre-treatment period from the undisturbed plot at the same location was used for the calculation.

Regression was used to estimate the rate of increase in juniper cover. Data from all untreated sites were analyzed using a general linear (PROC GLM, SAS 1989) model that contained a fixed effect for site and a linear regression coefficient for year. A separate analysis was conducted for treated sites using the same model except that the year of treatment was set to zero and all other years were expressed as the number of years post-treatment.

Analysis of variance was used to test for differences in rates of change in redberry juniper canopy cover from the time of treatment to the latest aerial photograph on chained or grubbed plots and for this same time interval on untreated plots. Locations $(n=5)$ were utilized as replications in this analysis.

Regression analysis was used to test for relationships between rates of juniper canopy cover change and average annual precipitation, median annual precipitation, and initial juniper cover. Precipitation data were from the weather station nearest to each study site (National Oceanic and Atmospheric Administration 1998).

Yearly redberry juniper canopy cover values were calculated for untreated rangeland (range 6 to $46 \%$ ) and subsequent to chaining or grubbing (range 1 to $30 \%$ ) using the respective estimates for the annual rates of cover change. These yearly juniper cover values were then used as the independent variable (X) in the natural log model of the relationship between annual herbage production (Y) and redberry juniper canopy cover (X) developed by Johnson et al. (1999) to estimate the decline in total herbaceous production as a function of time. The Johnson et al. (1999) production function is defined as:

$$
\mathrm{Y}=\mathrm{e}^{7.1626024-0.000441 \mathrm{X}^{2},}
$$

where $\mathrm{Y}=$ annual herbage production $(\mathrm{kg}$ $\left.\mathrm{ha}^{-1}\right), \mathrm{X}=$ redberry juniper canopy cover $(\%)$, and $\mathrm{e}=2.718282\left(\mathrm{r}^{2}=0.9054\right)$. Regression models were fitted to the data to quantify the change of annual herbage production as a function of time.

The Johnson (1999) natural log model and our estimates of the rates of increase in juniper cover were also used to estimate the impact of redberry juniper control on livestock carrying capacity. Analyses were conducted for pre-treatment juniper canopy cover values of 20 and $30 \%$. In these analyses, we assumed herbage production would reach maximum values in the second growing season following juniper control (Dye et al. 1995). We also assumed a $25 \%$ harvest efficiency for proper use (White and McGinty 1992) and that an animal unit (A.U.) consumed 11.8 $\mathrm{kg}$ of forage day ${ }^{-1}$ or $4,308 \mathrm{~kg}$ of forage 
year $^{-1}$ (oven-dry basis) (Range Term Glossary Committee 1974). Carrying capacity was calculated as animal unit years (A.U.Y.) section $^{-1}$ (259 ha). Treatment life $\left(\mathrm{TL}_{1}\right)$ was assumed to be the length of time (years) following treatment for carrying capacity to return to the pre-treatment level, and $\mathrm{TL}_{2}$ was the length of time (years) following treatment for carrying capacity to equilibrate with that which would have occurred in the absence of juniper control. Additional carrying capacity values, $\mathrm{ACC}_{1}$ and $\mathrm{ACC}_{2}$, were calculated as the difference between carrying capacity with and without juniper treatment for $\mathrm{TL}_{1}$ and $\mathrm{TL}_{2}$, respectively.

\section{Results and Discussion}

\section{Changes in Juniper Canopy Cover Untreated Rangeland}

Juniper canopy cover in the earliest aerial photographs of plots that were not treated ranged from 6 (Crockett County) to $33 \%$ (Irion County) (Fig. 2). These differences appeared to influence the rate of change in cover for 20 to 30 years. Juniper cover decreased or remained relatively static for several years after the mid 1950s on untreated sites where the initial cover was $>30 \%$ (see Irion and Coke Counties, Fig. $2)$. In contrast, juniper cover steadily increased, usually at increasing rates, on untreated rangeland where the initial canopy cover was $<14 \%$ (see Crockett, Nolan, and Reagan Counties, Fig. 2). These differences suggest that, following the drought of the $1950 \mathrm{~s}$, intraspecific competition may have suppressed juniper growth and seedling recruitment rates on rangeland with heavy juniper cover, whereas adequate resources were available for growth and seedling recruitment on rangeland with light juniper cover.

The rate of juniper canopy cover change on untreated rangeland increased over time from the mid 1960s through 1996 at most sites (Fig. 2). Terminal rates of canopy cover change on untreated rangeland varied from 0.45 percentage units year $^{-1}$ in Irion County, where cover was approaching $38 \%$, to 1.08 percentage units year $^{-1}$ in Crockett County, where cover was approaching only $26 \%$ (Fig. 2). The Crockett County untreated site supported only $11 \%$ juniper cover in 1985 , which was much less than was present on the other untreated sites. This suggests that the environment of the Crockett County site from 1985-1996 was capable of support-
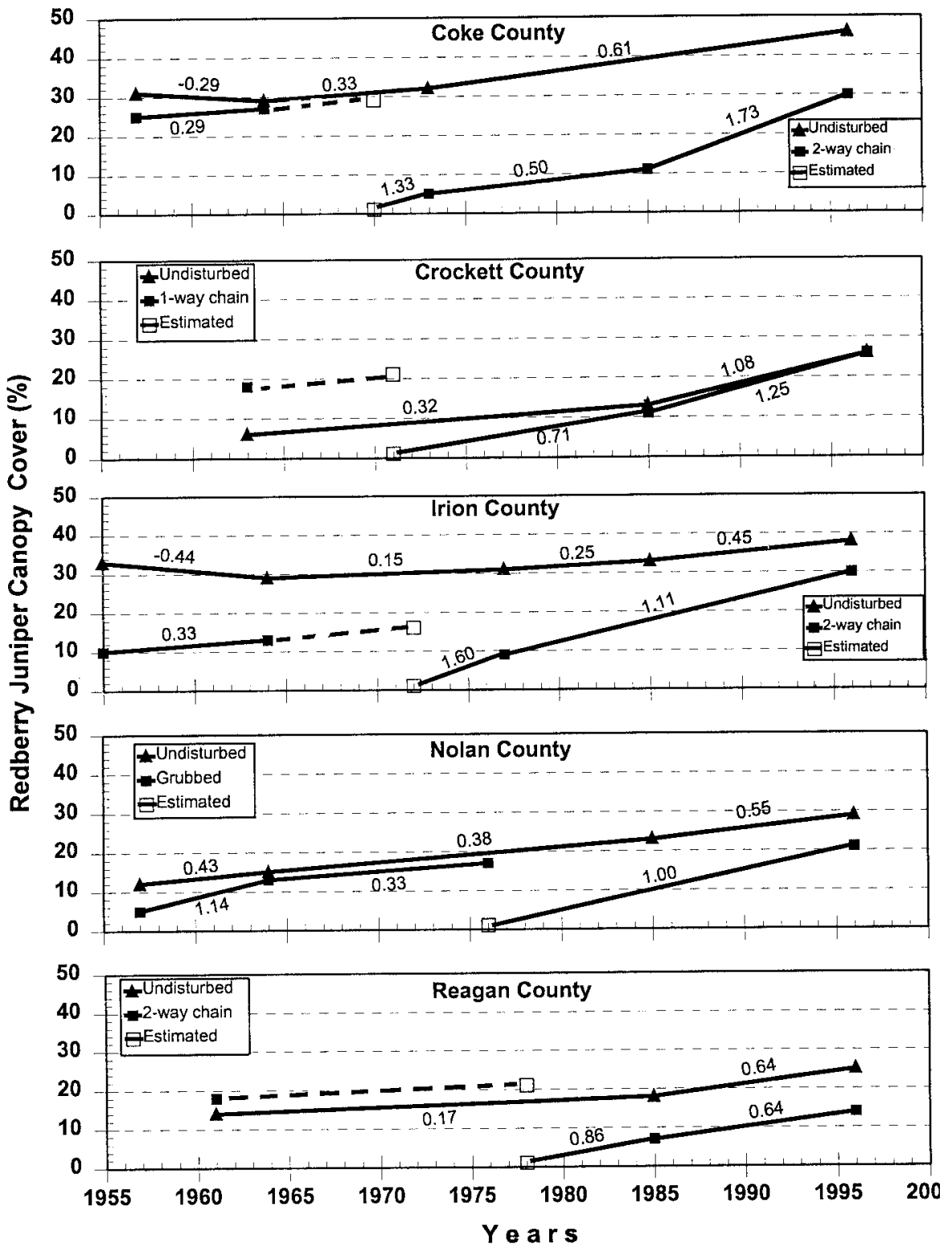

Fig. 2. Redberry juniper canopy cover (\%) from 1955 to 1997 on undisturbed rangeland and adjacent sites subjected to chaining or grubbing in Coke, Crockett, Irion, Nolan, and Reagan Counties, Tex. estimated from aerial photographs. Numbers between data points are the rates of canopy cover change (percentage units year ${ }^{-1}$ ). Standard errors of the means were too small (avg. 0.98, range 0.33 to 2.32 ) to show with vertical lines.

ing more juniper cover, whereas juniper populations on other undisturbed sites may have been more mature and perhaps approaching equilibrium with their environments.

Regression analysis revealed that the long-term rate of change in juniper canopy cover over 34- to 41-year periods on untreated sites was $0.35 \pm 0.06$ percentage units year $^{-1}(\mathrm{P}<0.001)$ (range 0.12 to $0.59)$. There were significant differences among sites for canopy cover, but regression coefficients were not different among the sites $(P>0.10)$. The untreated site in Irion County, which supported the greatest initial juniper cover (33\%) (Fig. 2), had the lowest long-term rate of change $(0.12)$. The site with the greatest long-term rate of change (0.59) was in Crockett County where average annual rainfall was similar to that for Irion County (Fig. 3), but where the initial juniper canopy cover was lowest (6\%) (Fig. 2). Regression analyses revealed no significant relationships between the long-term rate of juniper cover change and initial juniper cover, 


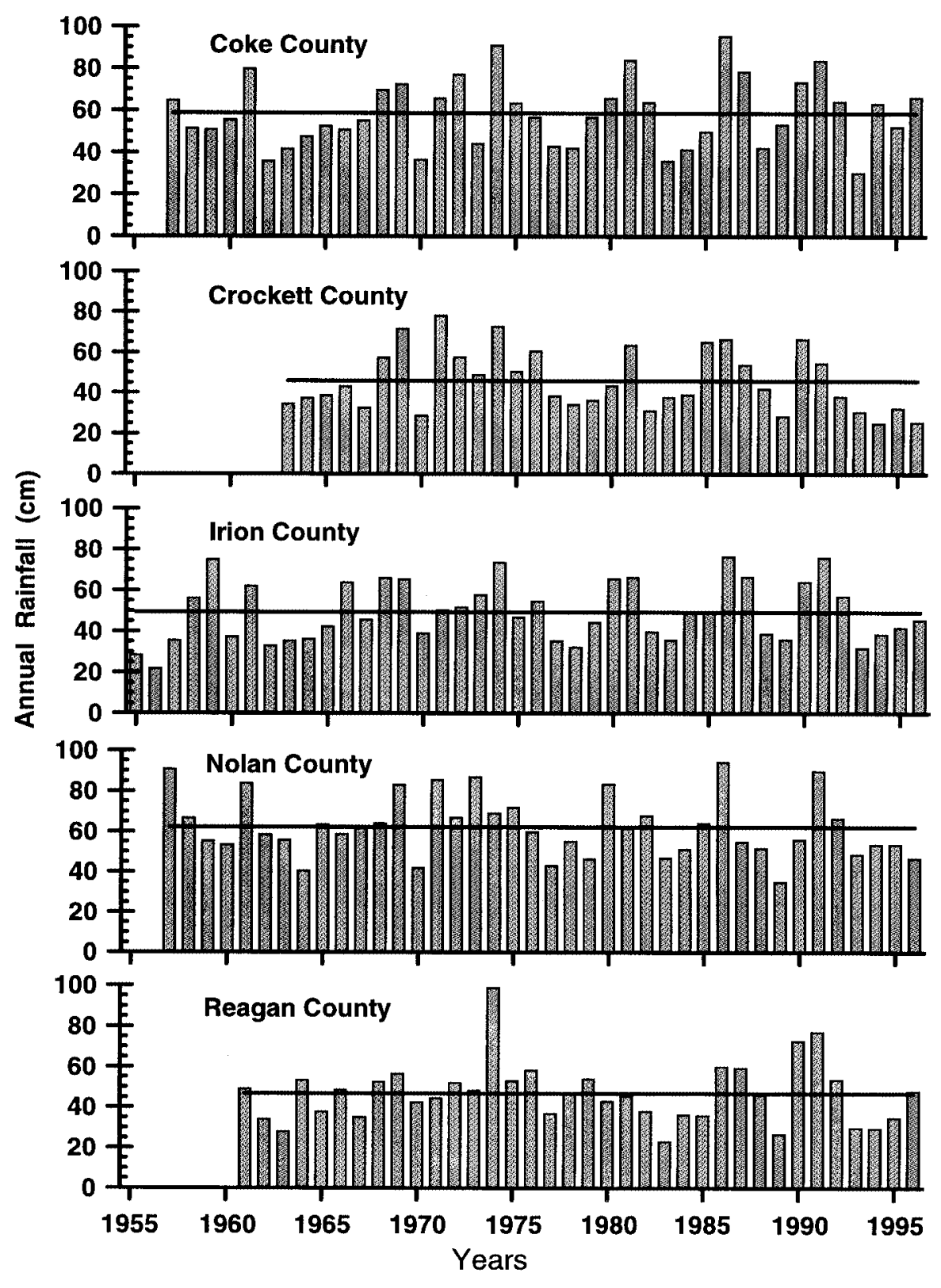

Fig. 3. Annual rainfall for the study periods (years covered by aerial photographs) for redberry juniper study sites in Coke, Crockett, Irion, Nolan, and Reagan Counties, Tex. Horizontal lines represent average annual rainfall for the study period.

average annual rainfall, or median annual rainfall on the 5 untreated sites $(\mathrm{P}>0.10)$. We speculate that interactions among many factors, including initial juniper cover, initial abundance of juvenile juniper plants, seedling recruitment rates, climatic variables that impact juniper growth and recruitment, and competition from the herbaceous understory would collectively account for the variation among sites in the long-term rate of juniper cover change. Redberry juniper is most likely to establish during cool, wet periods (Smith et al. 1975). McPherson and Wright (1990b) found that over half chaining or grubbing was $1.01 \pm 0.07$ percentage units year ${ }^{-1}(\mathrm{P}<0.0001)$ (range 0.72 in Reagan County to1.21 in Irion County). Site was not a significant source of variation $(\mathrm{P}>0.4)$ for canopy cover on the treated sites and regression coefficients were not different among sites $(\mathrm{P}>0.10)$. The rate of increase in juniper cover on treated sites was greater than the rate of $0.50 \pm 0.13$ percentage units year ${ }^{-1}$ that occurred during the same time interval (1970-78 to 1996-97) on untreated sites (P $=0.001)$.

Juniper cover returned to estimated pretreatment levels (avg. 21\%) in an average of 20 years (range 11 to 25 years) following chaining or grubbing at 4 of the treated sites (Fig. 2). Juniper cover had not returned to the estimated pre-treatment level by 1996 at the treated site in Reagan County. Regression analyses revealed that there were no relationships between the rate of juniper canopy cover increase following mechanical control and average or median annual precipitation or pre-treatment juniper cover at the sites studied (P > $0.10)$.

The rapid development of juniper cover following mechanical control can be attributed to 3 factors. Redberry juniper seedlings and saplings are often abundant in the understory of mature junipers in the Edwards Plateau (Ueckert and Whisenant 1982, Dye et al. 1995) and these small plants are not effectively controlled by chaining or grubbing. Chaining and grubbing reduce the competitive effects that mature junipers have on growth of these juvenile plants and they grow rapidly. On some sites, chaining simply removes the aboveground portion of large redberry junipers and these resprout from the basal caudex. Competition from associated vegetation has little impact on the growth rate of these plants. The growth rate of a resprouting juniper can approach 1,400 $\mathrm{cm}^{3}$ year $^{-1}$ (McPherson and Wright 1989). Also, the soil disturbance and juniper debris created by chaining and grubbing provides seedbeds and safe sites for juniper seed germination and seedling establishment.

\section{Relationship of Juniper Cover, Herbage Production, and Time}

The Johnson et al. (1999) natural log model predicted the declining trend in annual herbage production over time shown in Fig. 4 for untreated rangeland, utilizing 0.35 percentage units year ${ }^{-1}$ as the rate of increase in redberry juniper cover as cover thickens from 6 to $46 \%$. The mathematical model which fit this trend 


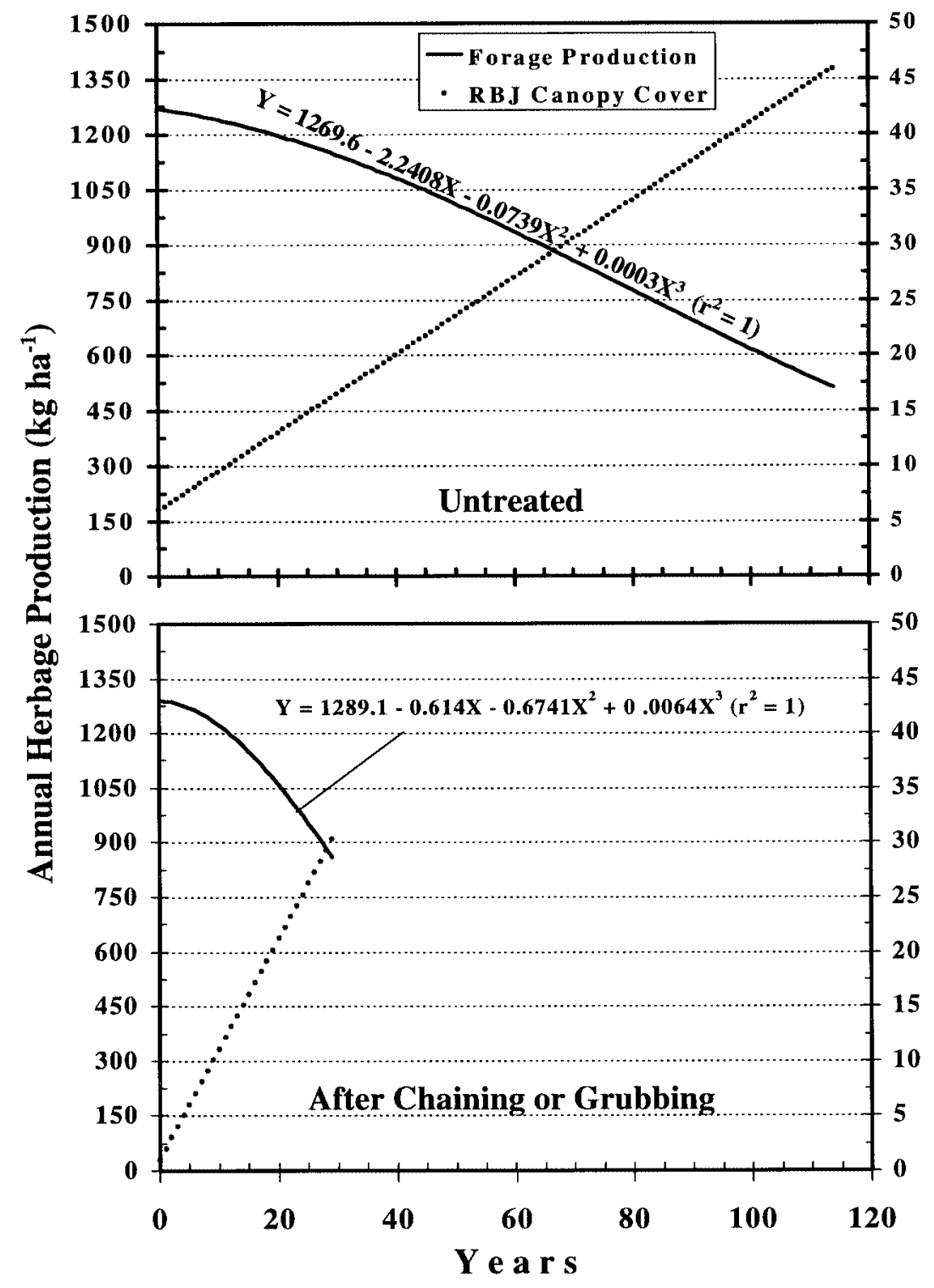

Fig. 4. Predicted trends in annual herbage production $\left(\mathrm{kg} \mathrm{ha}^{-1}, \mathrm{Y}\right)$ as a function of time (years, $X)$ for untreated and treated redberry juniper study sites. The curves were developed by integrating our estimates of annual redberry juniper canopy cover $(\%)$ into a natural log model of the relationship between annual herbage production and redberry juniper canopy cover (Johnson et al. 1999). The $\mathbf{r}^{2}$ value is 1.00 because the level of forage production estimated for a given level of juniper cover by the natural log equation is equal to the level of forage production estimated by the cubic equation using time (years) required for juniper cover to reach this level as the independent variable. Annual juniper canopy cover (dotted line) is included in each graph for reference only.

line was $\mathrm{Y}=1269.6-2.2408 \mathrm{X}-0.0739 \mathrm{X}^{2}$ $+0.0003 \mathrm{X}^{3}$, where $\mathrm{Y}=$ annual herbage production $\left(\mathrm{kg} \mathrm{ha}^{-1}\right)$ and $\mathrm{X}=$ time (years) $\left(r^{2}=1.00\right)$. The $r^{2}$ value is 1.00 because Johnson's natural log equation and our cubic equation are equivalent forms of the same relationship, i.e., the level of forage production estimated for a given level of juniper cover by the natural log equation is equal to the level of forage production estimated by the cubic equation using time (years) required for juniper cover to reach this level as the independent variable. The model indicates that annual herbage production declines at an increasing rate for about 80 years, or until juniper cover reaches $34 \%$, and then declines at a decreasing rate. The annual increments in herbage production decline were relatively low $\left(2.4\right.$ to $\left.5.0 \mathrm{~kg} \mathrm{ha}^{-1}\right)$ during years 0 through 22 as juniper cover increased from 6 to $14 \%$ and greatest $\left(>8 \mathrm{~kg} \mathrm{ha}^{-1}\right)$ during years 68 through 92 as juniper cover increased from 30 to $38 \%$. The model predicted that annual forage production would decrease by $60 \%(760 \mathrm{~kg}$ $\mathrm{ha}^{-1}$ ) as juniper cover increased from 6 to $46 \%$ over a period of 115 years (Fig. 4).

Using 1.01 percentage units year ${ }^{-1}$ as the rate of increase in juniper cover following mechanical control, the Johnson et al. (1999) natural log model predicted the decline in annual herbage production shown in Fig. 4 as juniper cover increased from 1 to $30 \%$. The mathematical model $\mathrm{Y}=1289.1-0.614 \mathrm{X}-0.6741 \mathrm{X}^{2}+$ $0.0064 X^{3}$, where $\mathrm{Y}=$ annual herbage production $\left(\mathrm{kg} \mathrm{ha}^{-1}\right)$ and $\mathrm{X}=$ time (years) fit these data $\left(r^{2}=1.00\right)$. This model predicted that the decline in annual herbage production would increase at a constantly increasing rate from $<2 \mathrm{~kg} \mathrm{ha}^{-1} \mathrm{yr}^{-1}$ in year 1 up to $23 \mathrm{~kg} \mathrm{ha}^{-1} \mathrm{yr}^{-1}$ in year 29 . Annual forage production would decline by $33 \%\left(429 \mathrm{~kg} \mathrm{ha}^{-1}\right)$ over a 29 -year period post-treatment as juniper cover increased from 1 to $30 \%$ (Fig. 4).

\section{Effect of Juniper Control on Livestock Carrying Capacity}

Economists must have some measure of production response to treatment over a realistic time frame to estimate the economic feasibility of alternative brush management practices (Conner 1985). The estimated impacts of controlling redberry juniper when infestations are at 20 and $30 \%$ canopy cover upon livestock carrying capacity are shown in Fig. 5. The treatment life of mechanical juniper control at $20 \%$ canopy cover was predicted at 19 years for carrying capacity to return to the pretreated production level $\left(\mathrm{TL}_{1}\right)$ and 29 years for carrying capacity of treated land to return to levels without treatment $\left(\mathrm{TL}_{2}\right)$ (Fig. 5). The corresponding values for additional livestock carrying capacity $\left(\mathrm{ACC}_{1}\right.$ and $\left.\mathrm{ACC}_{2}\right)$ due to treatment at $20 \%$ juniper cover were 38 and 71 A.U.Y. $259^{-1}$ ha for the 19- and 29-year periods, respectively. The treatment life was predicted at 29 and 44 years for $\mathrm{TL}_{1}$ and $\mathrm{TL}_{2}$, respectively, when juniper was controlled at $30 \%$ canopy cover (Fig. 5). Additional livestock carrying capacity due to treatment at $30 \%$ cover was 116 and 197 A.U.Y. $259^{-1}$ ha for the 29- and 44-year periods, respectively. Researchers have relied upon hypothetical response curves and the assumption that the level of production without treatment remains constant throughout the planning profile in some economic analyses of woody plant management practices (Conner 1985). Our data provide useful information which 

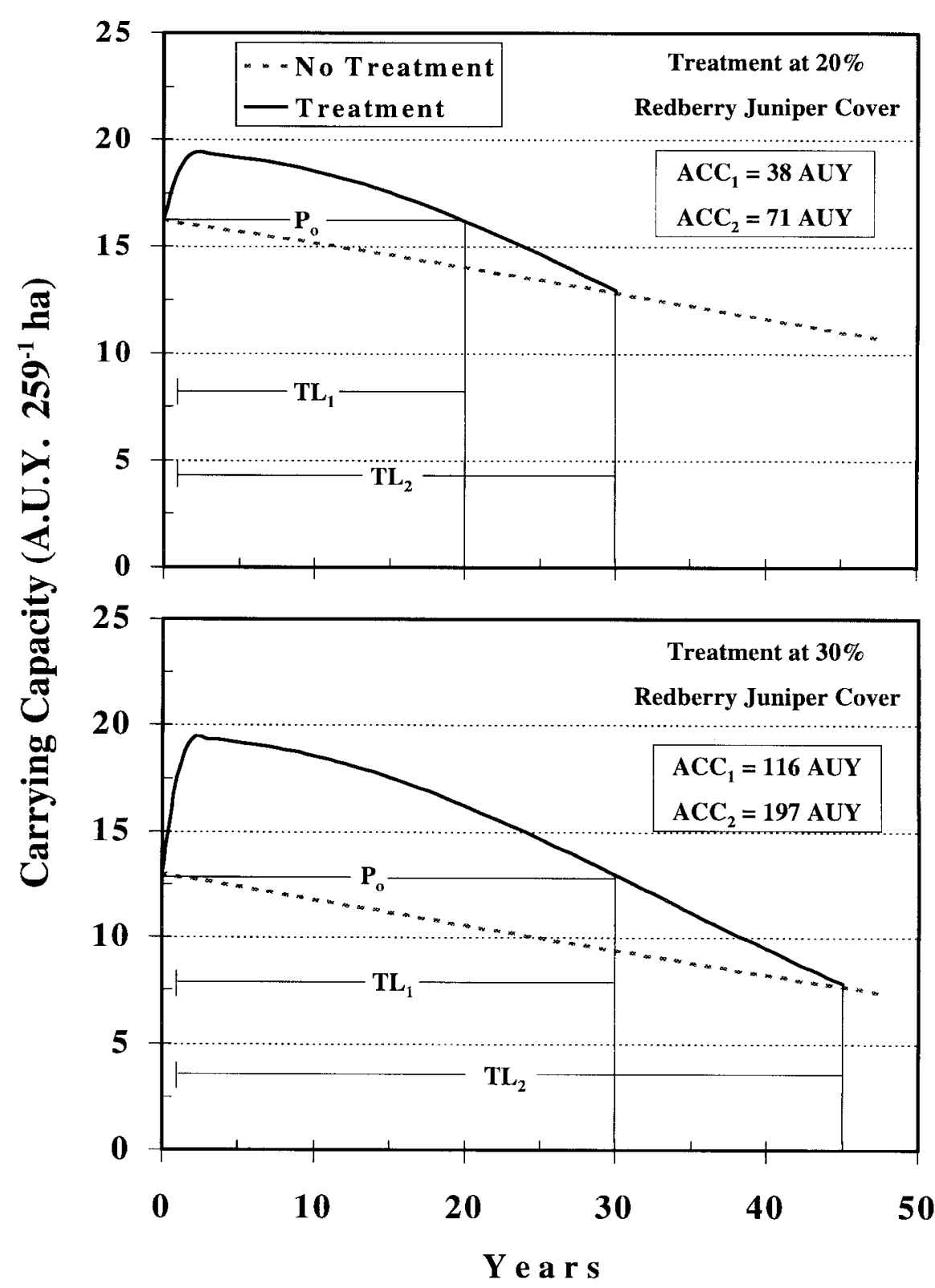

Fig. 5. Predicted livestock carrying capacity [A.U.Y. $259^{-1}$ ha, Y] as a function of time (years, $\mathrm{X}$ ) for untreated rangeland and rangeland treated for juniper control at 20 or $30 \%$ juniper canopy cover. $P_{0}$ is the pretreatment production level. Treatment was applied in year $1 . T L_{1}$ is the time (years) for production of treated rangeland to return to $P_{0}$. $T L_{2}$ is the time (years) for production of treated rangeland to return to the level without treatment. $\mathrm{ACC}_{1}$ and $\mathrm{ACC}_{2}$ values are the additional carrying capacities (A.U.Y.) due to treatment for $\mathrm{TL}_{1}$ and $\mathrm{TL}_{2}$ in each scenario.

economists can use to project annual production levels and realistic estimates of treatment life for redberry juniper control practices. The major differences between $\mathrm{ACC}_{1}$ and $\mathrm{ACC}_{2}$ values shown above definitely do not support use of the assumption that the level of production without treatment remains constant throughout the planning profile. $\mathrm{ACC}_{1}$ values were $>40 \%$ lower than $\mathrm{ACC}_{2}$ values. general reduction in diversity, density, basal area, and productivity of herbaceous plants; (2) an influx of secondary woody and succulent species; (3) further reduction in fire frequency and intensity; and (4) a high incidence and rate of additional juniper seedling recruitment (Dye et al. 1995). This study documents the rates at which redberry juniper woodlands develop and recover following chaining or grubbing and concomitant rates in decline of herbage production and carrying capacity. This study also substantiates the conclusion of Dye et al. (1995) that conversion of juniper woodlands back to grasslands will not only require initial reclamation treatments, but also maintenance control practices and proper grazing management. Redberry juniper canopy cover will increase at the rate of 1.01 percentage units year $^{-1}$ following mechanical control, thus the effective treatment life of a practice that reduces juniper cover by $20 \%$ will be about 20 years.

Our data show that annual herbage production on untreated juniper woodlands declines slowly as redberry juniper cover reaches about $14 \%$ but rapidly as juniper cover continues to increase above $20 \%$. We suggest that initial or maintenance control practices should be installed before redberry juniper cover exceeds $20 \%$, i.e. before annual herbage production begins declining at peak rates.

Knowledge of the rate of change in woody plant canopy cover is essential for estimating the expected treatment life of control practices and the decline in herbage production without treatment. This study provides quantitative information that should be helpful for studying the profitability of alternative juniper management practices. In a recent study of the economic feasibility of redberry juniper control using two-way chaining as the initial treatment and periodic prescribed burning as maintenance treatments, Johnson et al. (1999) utilized empirical rates of juniper cover change of 1.6, 2.5, and 5 percentage units year ${ }^{-1}$. Their study showed that net present value of juniper control treatments increased from $\$ 67$ to $\$ 130 \mathrm{ha}^{-1}$ and that the optimal burning cycle decreased from 9 to 5 years as the rate of juniper cover change increased from 1.6 to 5 percentage units year ${ }^{-1}$. The lower rates of increase in juniper cover that we report in this study $(0.35$ and 1.01 percentage units year ${ }^{-1}$ for untreated and treated rangeland, respectively) suggest that the net present value of controlling juniper with chaining and periodic burning would be substantially less than $\$ 67 \mathrm{ha}^{-1}$, 
and that the optimum burning interval would be longer than 9 years. The major differences in estimated productivity of treated and untreated rangeland reported in this study clearly indicate that it should not be assumed in economic studies that production of untreated rangeland would remain constant over the planning period.

Ranchers and rangeland resource managers should recognize that excessive grazing pressure gives juniper, which is relatively unpalatable, a competitive advantage over palatable forage species. Failure to reduce stocking rates as juniper cover increases will likely accelerate the rate of increase in juniper cover and the rate of decrease in herbage production and livestock carrying capacity.

\section{Literature Cited}

Ansley, R.J., W.E. Pinchak, and D.N. Ueckert. 1995. Changes in redberry juniper distribution in northwest Texas (1948-1992). Rangelands 17:49-53.

Ansley, R.J., X.B. Wu, and B.A. Kramp. 2001. Observation: Long-term increases in mesquite canopy cover in North Texas. J. Range Manage. 54:171-176.

Archer, S., C. Scifres, C.R. Bassham, and R. Maggio. 1988. Autogenic succession in a subtropicl savanna: conversion of grassland to thorn woodland. Ecol. Monogr. 58:111-127.

Barnhill, J.L. 1974. Soil survey of Coke County, Texas. USDA-SCS, Temple, Tex. and Texas Agr. Exp. Sta., College Station, Tex.

Bonham, C.D. 1989. Measurements for terrestrial vegetation. John Wiley \& Sons, Inc., New York, N.Y.
Conner, J.R. 1985. Technology selection based on economic criteria, p. 47-54. In: C.J. Scifres, W.T. Hamilton, J.R. Conner, J.M. Inglis, G.A. Rasmussen, R.P. Smith, J.W. Stuth, and T.G. Welch. Integrated brush management systems for South Texas: development and implementation. Texas Agr. Exp. Sta. Bull. B-1493.

Correll, D.S. and M.C. Johnston. 1970. Manual of the vascular plants of Texas. Texas Res. Foundation, Renner, Tex.

Dye, K.L., II, D.N. Ueckert, and S.G. Whisenant. 1995. Redberry juniper: herbaceous understory interactions. J. Range Manage. 48:100-107.

Ellis, D. and J.L. Schuster. 1968. Juniper age and distribution on an isolated butte in Garza County, Texas. Southwest. Natur. 13:343-348.

Hall, M.T. and C.J. Carr. 1968. Variability in Juniperus in the Palo Duro Canyon of western Texas. Southwest. Natur. 13: 75-98.

Johnson, P., A. Gerbolini, D. Ethridge, C. Britton, and D. Ueckert. 1999. Economics of redberry juniper control with burning in the Texas Rolling Plains. J. Range Manage. 52:569-574.

Knapp, P.A., P.L. Warren, and C.F. Hutchinson. 1990. The use of large-scale aerial photography to inventory and monitor arid rangeland vegetation. J. Environ. Manage. 31:29-38.

Lowther, A.C. 1981. Soil survey of Nolan County, Texas. USDA-SCS, Temple, Tex. and Texas Agr. Exp. Sta., College Station, Tex.

McPherson, G.R. and H.A. Wright. 1989. Direct effects of competition on individual juniper plants: a field study. J. Appl. Ecol. 26:979-988.

McPherson, G.R. and H.A. Wright. 1990a. Effects of cattle grazing and Juniperus pinchotii canopy cover on herb cover and production in western Texas. Amer. Midl. Natur. 123:144-151.
McPherson, G.R. and H.A. Wright. 1990b. Establishment of Juniperus pinchotii in western Texas: environmental effects. J. Arid Environ. 19:283-287.

National Oceanic and Atmospheric Administration. 1998. Climatological data for Texas. National Climate Center, Asheville, N.C.

Range Term Glossary Committee. 1974. A glossary of terms used in range management. Society for Range Management, Denver, Colo.

SAS Institute, Inc. 1989. SAS/STAT user's guide, Version 6, Fourth Ed., Vol. 2. SAS Institute, Inc., Cary, N.C.

Soil Conservation Service. 1985. Texas brush inventory. USDA-SCS, Temple, Tex.

Soulé, P.T. and P.A. Knapp. 1999. Western juniper expansion on adjacent disturbed and near-relict sites. J. Range Manage. 52:525-533.

Smith, M.A., H.A. Wright, and J.L. Schuster. 1975. Reproductive characteristics of redberry juniper. J. Range Manage. $28: 126-128$.

Thurow, T.L. and J.W. Hester. 1997. How an increase or reduction in juniper cover alters rangeland hydrology, Ch. 4, p. 9-22. In: C.A. Taylor, Jr. (ed.), Proc. 1997 Juniper Symposium. Texas Agr. Exp. Sta. Tech. Rep. 97-1, San Angelo, Tex.

Ueckert, D.N. and S.G. Whisenant. 1982. Individual plant treatments for controlling redberry juniper seedlings. J. Range Manage. 35:419-423.

White, L.D. and A. McGinty. 1992. Stocking rate decisions. Texas Agr. Ext. Serv. Bull. B5036

Wiedenfeld, C.C. 1986. Soil survey of Irion County, Texas. USDA-SCS, Temple, Tex. and Texas Agr. Exp. Sta., College Station, Tex.

Wu, X.B., T.L. Thurow, and S.G. Whisenant. 2000. Fragmentation and changes in hydrologic function of tiger bush landscapes, southwest Niger. J. Ecol. 88:790-800. 